\title{
2000-2020: twenty years later, where are we in terms of the unity of international law?*
}

\author{
Pierre-Marie Dupuy** \\ Emeritus Professor of International Law \\ University of Paris (Panthéon-Assas), France \\ Graduate Institute of International and Development Studies, Geneva, Switzerland
}

Twenty years have passed since the author's delivery in 2000 of the general course of public international law at the Hague Academy of International Law, titled 'The Unity of the International Legal Order'. That course was designed to combat the all-too-common idea that international law was in the process of 'fragmentation'. It did so by developing a theory focused on the existence of and tension between two forms of unity in the international legal order: the formal unity (concerning the procedures by which primary norms are created and interpreted, and their non-compliance adjudicated) and the material unity (based on the content of certain norms of general international law, peremptory norms). Twenty years later, the time is ripe to revisit this theory to determine the extent to which it is still valid as a framework for the analysis of international law, particularly as an increasing number of 'populist' leaders very much seem to ignore, or voluntarily deny, the validity of some of the key substantial principles on which the international legal order was refounded within and around the United Nations in 1945. When confronted with the factual reality of the present state of international relations as well as with the evolution of the law, one can conclude that the validity of the unity of the international legal order is unfailingly maintained, and that its role in upholding the international rule of law is more important now than ever.

Keywords: international legal order, fragmentation, formal and material unity, peremptory norms, erga omnes obligations, International Court of Justice

\section{INTRODUCTION}

Twenty years is a period of time in which the passage from one generation to another has long been recognised. It is also the name of a famous novel by Alexandre Dumas in which he tells the story of the three (plus one) musketeers and their adventures! ${ }^{1}$ In a less picaresque and more modest way, it is also the time that has elapsed since I had the chance to give, at an early age for this kind of exercise, my general course of public international law at The Hague Academy of International Law, The Netherlands. That

* This paper is based on the lecture presented as the joint Cambridge International Law Journal-Lauterpacht Centre for International Law 2019-2020 Annual Lecture, delivered at the Lauterpacht Centre for International Law at the University of Cambridge, UK, on 22 November 2019.

** 2015 ASIL Manley Hudson Medallist.

1. Alexandre Dumas, Twenty Years After (George Routledge and Sons, London 1878). 
course was entitled 'The Unity of the International Legal Order'. ${ }^{2}$ From its very title, it was intended to combat the all-too-common idea that international law is in the process of 'fragmentation'. This idea, which to all intents and purposes remained rather confused, had nevertheless been rapidly adopted by a significant part of the legal literature. This general course was published in 2003. Three years later, in 2006, the 'Conclusions of the Work of the Study Group on the Fragmentation of International Law' ${ }^{3}$ met a good part of the same conclusions in finalising the work of the International Law Commission (ILC) on the topic of fragmentation. Far from consecrating the existence of the phenomenon referred to by the catch-all concept of 'fragmentation', the members of the Study Group insisted, on the contrary, on what precisely makes up the unity of international law, envisaged as a legal order. This notion of a legal order, which it seems necessary to distinguish from the less precise notion of a 'legal system', was envisaged in the above-mentioned general course by reference to the respective theories of Kelsen, Santi Romano, Scelle and Hart: ${ }^{4}$ it is understood here as referring to an organised set of norms establishing, at the very least, the way in which these norms are created and modified as well as the relationship between the rights and obligations of the subjects to which they apply and the consequences attached to their violation. Other elements are to be taken into consideration, which it would take too long to examine here, such as the institutional dimension and the possibility of a hierarchy of norms.

Still, in many respects, in the year 2000, international law seemed assured of a future that was much brighter than it is today! The last decade of the twentieth century saw the completion of the Uruguay Round, which marked the birth of a new organisation, the World Trade Organization (WTO), whose ambition was to complete and considerably expand the impact of the first General Agreement on Tariffs and Trade (GATT) in multilaterally regulating international trade. ${ }^{5}$ The WTO provided this area with a quasi-judicial mode of legal control and strictly regulated the legal recourse by States to trade countermeasures. ${ }^{6}$ The consecration of multilateralism thus seemed to be confirmed in the field of international economic and trade relations. In addition, arbitral case law on the settlement of disputes between States and private foreign investors was taking off. In a completely different field, the creation of the International Criminal Court was the culmination of the emergence of genuine international criminal law, which finally designated the individual as the holder not only of rights but also of obligations for which he or she could be held criminally responsible, both in the international and domestic order. ${ }^{7}$ The United Nations, for its part, had experienced from 1990 onwards (albeit for a brief period) a completely new

2. Pierre-Marie Dupuy, 'L'unité de l'ordre juridique international' (2002) 297 Recueil des Cours de l'Académie de Droit International 9.

3. ILC, 'Conclusions of the Work of the Study Group on the Fragmentation of International Law: Difficulties Arising from the Diversification and Expansion of International Law' (2006) II

(2) Yearbook of the International Law Commission 175, 177-184.

4. Dupuy (n 2) 67-77.

5. Marrakesh Agreement Establishing the World Trade Organization (adopted 15 April 1994, entered into force 1 January 1995) 1867 UNTS 3, preamble, art 1.

6. Jan Wouters and Bart De Meester, The World Trade Organization: A Legal and Institutional Analysis (Intersentia, Antwerp 2007) 19-22, 227.

7. Statute of the International Criminal Court (adopted 17 July 1998, entered into force 1 July 2002) 2187 UNTS 90, arts 1, 25. Also see generally Antonio Cassese, Paola Gaeta and John Jones (eds), The Rome Statute of the International Criminal Court: A Commentary, vol 1 (OUP, Oxford 2002). 
cohesion; it enabled the Security Council to broaden the frontiers of peacekeeping, in theory and in practice. ${ }^{8}$ This was particularly the case in the complex context of the new Balkan conflict, which ended with the attribution to the United Nations itself of a territorial mandate, limited but without any real precedent, precisely in order to restore and consolidate peace in the territory of Kosovo. ${ }^{9}$

Moreover, the passage from one century to the next at the time I was giving my lecture prompted me to attempt an overall assessment of the evolution of this legal order since its re-founding in 1945, marked by the birth and development of an ever more ramified institutional structure. From the 1960s onwards, the United Nations and the Specialized Agencies had established themselves as the framework for welcoming the States resulting from decolonisation, a phenomenon which had led, in nearly 20 years, to an almost fourfold increase in the number of members of the "World Organization', the United Nations and the Specialized Agencies jointly. The assertion of permanent sovereignty over natural resources offered hope for a reduction in the dependence of developing countries on investors from developed countries. Moreover, the Stockholm Declaration adopted in 1972 and confirmed 20 years later, in 1992, seemed to attest that the 'international community' as a whole had finally come to realise that 'we have only one earth' and that the protection of the human environment requires increased consultation and cooperation on a global scale.

Everywhere, the multiplication of fields now regulated by international law had led to the multiplication of international conventions. Several of the new conventions were endowed with their own 'follow-up machinery', which often too rapidly engendered the suggestion that such a feature transformed them into 'self-contained regimes', as if their relative autonomy made these conventional regimes totally independent of general international law, which is an illusion. ${ }^{10}$ In reality, all these developments, far from being a guarantee of the 'fragmentation' of international law, were in fact manifestations of its growing complexity. At the same time, a new type of legal rule had also emerged, this time in the normative order; these were designated precisely by the fact that they were no longer intended to be merely mandatory but peremptory, ie not subject to derogation. The notion of an 'international community of States as a whole', to which this peremptory law referred, ${ }^{11}$ thus took on a normative dimension. Indeed, 20 years ago, in July 2000, just over a year before the twin towers of Manhattan collapsed, inaugurating the globalisation of terrorism, the profession of a professor of international law, without going so far as to allow for adventures as exhilarating as those of the four musketeers, made it possible to invite new generations of students to engage in particularly stimulating reflections! Personally, the situation encouraged me to sketch out an overall theory designed to take account of the factors of unity but also of tension existing within the international legal order itself.

In order to be able to examine to what extent this theory, as a framework for a dynamic analysis of the law, seems to me still valid today, it is necessary, first of all, to recall its main terms (Section 2), before comparing it with the developments that have taken place since then (Section 3).

8. Report of the Secretary General, 'An Agenda for Peace: Preventive Diplomacy, Peacemaking and Peace-Keeping' (1992) UN Doc A/47/277-S/24111, paras 3 and 8-19.

9. Bernhard Knoll, The Legal Status of Territories Subject to Administration by International Organisations (CUP, Cambridge 2008) 46-47.

10. Bruno Simma and Dirk Pulkowski, 'Of Planets and the Universe: Self-Contained Regimes in International Law' (2006) 17 European Journal of International Law (EJIL) 484, 507-510.

11. Vienna Convention on the Law of Treaties (adopted 23 May 1969, entered into force 27 January 1980) 1155 UNTS 331 (VCLT) art 53. 


\section{THE THEORY OF THE TWO FOUNDATIONS OF THE UNITY OF THE INTERNATIONAL LEGAL ORDER}

The whole general course taught at the Hague Academy in 2000 was built around the idea that, far from being fragmented, the international legal order is in fact driven by the conjunction, but also the competition, between two distinct principles. One that is ancient, if not even traditional, is the principle of the formal unity of international law, its forms having known, over time, few drastic innovations. The other, quite the opposite, is material unity, which has appeared on a historical scale very recently, in the latter two-thirds of the twentieth century, with the affirmation of jus cogens, which no longer concerns form but substance, ie the content of some of the norms of general international law. By the very fact of their definition, these norms are called upon to occupy a predominant position in a hierarchical scale, since they are non-derogable.

\subsection{The formal unity}

At least since the adoption of the Treaties of Westphalia, international law has found its unity in the technical means it places at the disposal of States to organise their coexistence and even their cooperation. Indeed, neither the sources of law nor their mode of operation is affected by the purpose of existing norms; they are, in other words, indifferent to their field of intervention. Thus, the forms in which treaties were and still are established remain fundamentally the same as they have almost always been - one could almost say since the dawn of time, as is evidenced, for example, by the form of the Treaty of Qadesh, concluded in 1270 BC between Pharaoh Ramses II and his counterpart Hatusili I, Emperor of the Hittites. ${ }^{12}$ Whether it is a question of concluding a peace treaty, determining the delimitation of borders, maritime or land, between two States, or defining the terms of trade between two or more partners, etc, the 'secondary norms', as Hart understood this expression, ${ }^{13}$ remain the same. Even treaties setting out fundamental human rights do not escape these rules, despite some specificities linked to the lifting, in their case, of the condition of reciprocity.

At the same time, it is true that the development of the institutional phenomenon, through the multiplication of international organisations, had, from 1945 onwards, more markedly than in the inter-war period, significantly modified relations between States in the now ordinary framework of multilateralism. This had led to a significant change in the conditions for the formation of customary rules which have certainly evolved, particularly as a result of the acceleration of the process of expressing collective opinio juris though soft law. Such a phenomenon may be explained by the partial institutionalisation of inter-State discussions with a normative purpose, by which Prosper Weil had been so moved. ${ }^{14}$ However, these developments are perceptible in all fields open to the formation of customary rules, including, among other examples, those concerning the law of space or environmental law, the law of maritime spaces, and human rights law. These developments do not fundamentally call into question the formal unity of the conditions for the creation of customary norms, nor do they call into question conventional norms, which remain dominated by the expression of

12. Dupuy (n 2) 80-86.

13. Herbert Hart, The Concept of Law (3rd edn, OUP, Oxford 2012) 91-99.

14. Prosper Weil, 'Towards Relative Normativity in International Law?' (1983) 77 American Journal of International Law (AJIL) 413, 434-436. 
State consent. To sum up, it can be said that the formal unity of the international legal order is essentially constituted by what Hart calls in his terminology secondary rules, ie the normative technology applicable to the management of substantive, ie primary, norms. ${ }^{15}$ It is precisely within the latter that the material unity of the international legal order has been affirmed, albeit potentially.

\subsection{The material unity}

In May 1969, an exceptional event occurred: the appearance of a new type of norm! It cannot be said that this innovation was unprecedented. As shown by the reports of successive Special Rapporteurs to the ILC, in particular those of Sir Humphrey Waldock, ${ }^{16}$ the notion of peremptory norms of international law can be traced at least back to the still famous writings of Alfred Verdross in the 1930s. ${ }^{17}$ It was also heralded by the writings of Hersch Lauterpacht, who stressed the social importance of certain international norms by pointing to 'such overriding principles of international law which may be regarded as constituting principles of international public policy'. ${ }^{18}$ The Member States of the United Nations meeting at the Vienna Conference on the Law of Treaties accepted the proposals made to them by the ILC concerning this particular category of norms. In this connection, without being able to repeat here the detailed analyses carried out in my general course, it is appropriate to restate carefully the very famous Article 53 of the Vienna Convention on the Law of Treaties (Vienna Convention or VCLT):

\section{Article 53: TREATIES CONFLICTING WITH A PEREMPTORY NORM OF GENERAL} INTERNATIONAL LAW ('JUS COGENS')

A treaty is void if, at the time of its conclusion, it conflicts with a peremptory norm of general international law. For the purposes of the present Convention, a peremptory norm of general international law is a norm accepted and recognized by the international community of States as a whole as a norm from which no derogation is permitted and which can be modified only by a subsequent norm of general international law having the same character. ${ }^{19}$

There are at least two fundamental elements to be noted here. The first is that the fact of the existence of a category of norms called peremptory norms does not come

15. Hart (n 13) 94.

16. ILC, 'Second Report on the Law of Treaties, by Sir Humphrey Waldock, Special Rapporteur' (1963) UN Doc A/CN.4/156 and Add.1-3, 52, para 1 and see further reference to jus cogens at 39, 52-54, 59, 61, 78-79, 94 of his Second report and in his subsequent reports: ILC, 'Third Report on the Law of Treaties, by Sir Humphrey Waldock, Special Rapporteur' (1964) UN Doc A/CN.4/167 and Add.1-3, 35-37, 43-44; ILC, 'Fourth Report on the Law of Treaties, by Sir Humphrey Waldock, Special Rapporteur' (1965) UN Doc A/CN.4/177 and Add.1-2, 18, 29; ILC, 'Fifth Report on the Law of Treaties, by Sir Humphrey Waldock, Special Rapporteur' (1966) UN Doc A/CN.4/183 and Add.1-4, 6, 8-9, 19-25, 45-46; ILC, 'Sixth Report on the Law of Treaties, by Sir Humphrey Waldock, Special Rapporteur' (1966) UN Doc A/CN.4/186 and Add.1-7, 54, 56-57, 59, 76.

17. Alfred von Verdross, 'Heilige und unsittliche Staatsverträge' (1935/1936) 2 Völkerbund und Völkerrecht 164; Alfred von Verdross, 'Forbidden Treaties in International Law' (1937) 31 AJIL 571; Gaetano Morelli, 'A proposito di norme internazionali cogenti' (1968) 51 Rivista di diritto internazionale (RDI) 108.

18. ILC, 'Report on the Law of Treaties by Mr. H. Lauterpacht, Special Rapporteur' (1953) UN Doc A/CN.4/63, 155, para 4.

19. VCLT (n 11) art 53. 
from heaven, as if it were a return to the tradition of natural law. It is the result of the agreement of States. The assertion that there is jus cogens is 'accepted and recognized by the international community of States'. There is therefore no revolution here as to the origin of these norms: they result from the agreement of sovereign States like all the others, and the voluntarist positivists should be satisfied with them by noticing, here as elsewhere, what is the fruit of convergent State wills. ${ }^{20}$ The second fundamental element to be drawn from the text of the above-mentioned Article 53 is that this State will is expressed in a sufficiently coherent and generalised manner to be identified as the opinio juris emanating from an international community. This refers to the existence of a certain type of social, if not even ideological, solidarity between the different types of States sharing the planet, a notable affirmation at a time, 1969, when the economic and political divisions between States were particularly sensitive (ie the East/West confrontation).

Here, it must be understood that the question of whether this community in fact presents sufficient coherence and understanding between its members to be effective is not relevant in law. The above-mentioned Article 53 and, as a result, many subsequent international legal instruments posit that such a community does exist. This means that, as a matter of law, the existence of this international community of States cannot be doubted. To the extent that the law is disproved by the facts, as it often is, we would then not forget that we are here facing a legal fiction, ie a legal reality distinct from the factual reality; ${ }^{21}$ it is a well-known technique to which law, both international and domestic, often resorts. It is, for example, as true in law to say that all sovereign States are equal as it is to say, as is done in domestic law, that no one is supposed to ignore the law. This is true in law, and jurists, even if they have a duty to be lucid with regard to the actual reality of international relations, must know how to be content with this in their legal analysis of a given situation.

\subsection{Comparison of the two principles of unity}

One must be aware of the profound difference between formal unity, which is ancient and corroborated by the ordinary practice of international law, and material unity, an innovation which has only recently appeared on a historical scale, and whose affirmation is due to a normative logic inspired by the Charter of the United Nations (UN Charter) itself. The forms of law are neutral in essence. Material unity, by contrast, is the incorporation into certain legal norms of ethical or political values, which are themselves produced by one or more ideologies that are intertwined as dependent on the weight of history. Nothing is less neutral than material unity, whose identity, contrary to what was said by many authors at the outset, is fairly easily identifiable. It includes the rules enshrining the main rights and freedoms relating to respect for the human being, the fundamental rights of peoples, but also certain principles directly governing relations between States, such as the principle of sovereign equality (implying non-interference in internal affairs and to which an advisory opinion of the International Court of Justice (ICJ or the Court) added in 1996 the right of each State to its own survival). ${ }^{22}$

20. Dupuy (n 2) 277.

21. Ibid 245-268; Geoffrey Samuel, 'Is Law a Fiction?' in William Twining and Maksymilian Del Mar (eds), Legal Fiction in Theory and Practice (Springer, Cham 2015) 31, 49-51.

22. Legality of the Threat or Use of Nuclear Weapons (Advisory Opinion) [1996] ICJ Rep 226, 263 [96]. 
Contrary to what the ICJ believed it could affirm in a certain context, to which we shall return later, it would be illogical to assert that there is no link between formal and material unity. On the contrary, the one is at the service of the other, just as secondary norms, which are norms regulating the use of other norms ${ }^{23}$ are at the service of the management of primary norms. This in particular was brilliantly demonstrated by Norberto Bobbio. ${ }^{24}$ It is particularly the case in the context of the jurisdictional function assumed by the judge, responsible for pronouncing the sanction (secondary because consecutive) for the violation of a primary norm. This distinction, as recalled by Bobbio, is all the better established as it goes back to Jhering and not to Hart. ${ }^{25}$ It is precisely for this fundamental theoretical reason that a rigid separation cannot be established between primary norms (to which jus cogens in particular belong) and secondary norms. In addition, in many cases a norm (in particular those relating to the jurisdictional immunity of States) may be assessed both from the point of view of a secondary norm (insofar as it is a norm of adjudication) and from that of a primary norm deriving directly from the principle of the sovereign equality of States, as is recalled at Article 2(1) of the UN Charter.

The assertion of a substantive unity of the international legal order prompts comparison with domestic legal orders, particularly those dominated by a written constitution in which, as is the case for example with the constitution of the Federal Republic of Germany or that of France, a number of substantive rules are designated as being of particular importance for the national community. ${ }^{26}$ However, unlike the domestic legal order, the established international legal order continues to be affected by certain shortcomings, in particular the absence of institutions designed to guarantee the continuity of the paramount importance attached to the supra-legality of peremptory norms. No permanent jurisdiction has been established in the international order other than subject to the prior consent of States, which in fact maintains courts and tribunals in the relative dependence of the latter. Nor, more widely, is a separation of powers in the sense of domestic constitutional law as understood by John Lock or Montesquieu is to be found in international law. This is reflected, as we shall see later, in the initial reluctance and then the manifest embarrassment with which the ICJ ended up accepting quite late the concept of peremptory norms (in 2006) without always wishing to draw the most logical normative consequences from this statement. ${ }^{27}$

\title{
3 THE THEORY OF THE TWO FOUNDATIONS OF UNITY PUT TO THE TEST OF REALITY SINCE THE YEAR 2000
}

Since the year 2000, many things have happened, some of which are likely to have had an impact on the general physiognomy of the international legal order or on some of its

\author{
23. Hart (n 13) 94. \\ 24. Norberto Bobbio, Essais de théorie du droit (Bruylant/LGDJ, Brussels/Paris 1998) 159-173. \\ 25. Ibid 160 . \\ 26. Basic Law for the Federal Republic of Germany 1949, arts 1, 20, 21, 79; Constitution of \\ the Fifth Republic 1958, preamble, arts 1-4. \\ 27. Pierre-Marie Dupuy, 'Le juge et la règle générale' (1989) 93 Revue générale de droit inter- \\ national public 569, reprinted in Pierre-Marie Dupuy, Ordre juridique et désordre international \\ (Pedone, Paris 2018) 107.
}


features. In particular, the towers of Manhattan have collapsed, opening up a new dimension to the universal spread of international terrorism, particularly Islamic terrorism, that is transboundary in nature. Hopes for a new expansion of multilateralism in international trade are tarnished by the adoption of specific interregional agreements and the systematic attacks on free trade that are so vigorously under way. The exponential expansion of information technology and 'social networks' has already brought the international community (and not only that of States) into the dizzying and largely uncontrolled era of digitalisation, which is equally transboundary in nature. Finally, the accelerated degradation of the environment on a global scale has taken on proportions that have surprised even the most pessimistic scientists by their intensity and speed. These developments concern, first of all, facts whose legal implications are not always discernible because of the lack of a sufficient distance in time. From the point of view of the law proper, we shall take up again, here too, the distinction between formal and material unity to see how each of them has (or has not) evolved.

\subsection{Formal unity: an evolution?}

As regards formal unity - that is, the way in which international legal norms are adopted, modified or their non-compliance sanctioned - it can be said that, for the last 20 years, there has been no real change, or at least no change that is radical in nature. On the contrary, an overall stability is evident. If I may refer to my personal experience as a legal practitioner (as counsel for several States before the ICJ or as an arbitrator or even chairman of arbitral tribunals), it seems reasonable to state that, from a formal point of view, international law appears to be basically the same. In other words, secondary norms remain essentially what they used to be some 20 years ago and there is no surprise about that. In particular, the relative proliferation of new judicial bodies has not provoked the proliferation of conflicting case law. Nevertheless, certain not insignificant developments are to be noted in the field of 'adjudicative' norms, in the sense of Hart; it is known that this type of norm concerns, in particular, the rules relating to the consequences of the violation of a primary norm, ie those governing the international responsibility of States. Two observations have to be made in this respect when assessing what has happened in the last two decades. Both illustrate the relationship established between the codification work within the ILC on the responsibility of States for internationally wrongful acts, on the one hand, and the jurisprudence of the ICJ, on the other.

The first concerns, with regard to wrongful acts of a continuing character, ${ }^{28}$ the broadening of the scope of the international responsibility of States. This legal institution was essentially turned towards the past, as it is aimed at re-establishing the situation which prevailed before the commission of the wrongful act. Now, this goal is completed by a second one, namely the obligation of the responsible State, pronounced by the Court most often on the initiative of the applicant, not to repeat in the future the production of the same wrongful act. This assurance of non-repetition is found in particular in the LaGrand (Germany v United States of America), ${ }^{29}$ Land and Maritime

28. Giovanni Distefano, 'Fait Continu, Fait Compose et Fait Complexe dans le Droit de la Responsabilité' (2006) 52 Annuaire français de droit international 1.

29. LaGrand (Germany v United States of America) (Judgment) [2001] ICJ Rep 466, 512-513 [123]-[124]. 
Boundary Between Cameroon and Nigeria ${ }^{30}$ Avena (Mexico v United States of America), ${ }^{31}$ Armed Activities on the Territory of the Congo (Democratic Republic of the Congo v Uganda), ${ }^{32}$ Application of the Convention on the Prevention and Punishment of the Crime of Genocide (Bosnia and Herzegovina v Serbia and Montenegro), ${ }^{33}$ Dispute Regarding Navigational and Related Rights (Costa Rica $v$ Nicaragua), ${ }^{34}$ Pulp Mills on the River Uruguay (Argentina v Uruguay), ${ }^{35}$ Jurisdictional Immunities of the State (Germany $v$ Italy), ${ }^{36}$ and Certain Activities Carried Out by Nicaragua in the Border Area (Costa Rica v Nicaragua). ${ }^{37}$ It is therefore now well established that the obligation of cessation of the continuing wrongful act is accompanied by an assurance of non-repetition of the same type of wrongful act in the future. If such an assurance is not explicitly requested, then the Court makes it clear that 'there is no reason to suppose that a State whose act or conduct has been declared wrongful by the Court will repeat that act or conduct in the future, since its good faith must be presumed' ${ }^{38}$ but this is another way to set out that the assurances of non-repetition are in contemporary times ordinarily implied by the declaration of wrongfulness of a determined continuous conduct. International case law has thus almost instantaneously (as early as 2001) incorporated into positive law the proposal for the 'progressive development' of the law which was formulated in Article 30(b) of the draft codification of the international responsibility of States as defined by the work of the ILC. ${ }^{39}$ It may, of course, be considered that the guarantee of non-repetition was logically implied by the obligation of cessation. Nevertheless, this link had not yet been affirmed in practice before the LaGrand judgment and the successive cases which took up the requirement initially formulated by Germany, on the basis of the work of the ILC as codifier. This development is also to be seen in relation to the broader conception of liability litigation inaugurated by the first Special Rapporteur, Roberto Ago,

30. Land and Maritime Boundary Between Cameroon and Nigeria (Cameroon v Nigeria: Equatorial Guinea intervening) (Judgment) [2002] ICJ Rep 303, 452 [318]-[319].

31. Avena and Other Mexican Nationals (Mexico v United States of America) (Judgment) [2004] ICJ Rep 12, 68-69 [149]-[150].

32. Armed Activities on the Territory of the Congo (Democratic Republic of the Congo $v$ Uganda) (Judgment) [2005] ICJ Rep 168, 255-256 [255]-[257].

33. Application of the Convention on the Prevention and Punishment of the Crime of Genocide (Bosnia and Herzegovina v Serbia and Montenegro) (Judgment) [2007] ICJ Rep 43 (Bosnia Genocide) 235-236 [466].

34. Dispute Regarding Navigational and Related Rights (Costa Rica v Nicaragua) (Judgment) [2009] ICJ Rep 213, 267 [150].

35. Pulp Mills on the River Uruguay (Argentina v Uruguay) (Judgment) [2010] ICJ Rep 14, 104-105 [277]-[280].

36. Jurisdictional Immunities of the State (Germany v Italy: Greece intervening) (Judgment) [2012] ICJ Rep 99, 154 [138].

37. Certain Activities Carried Out by Nicaragua in the Border Area (Costa Rica v Nicaragua) and Construction of a Road in Costa Rica Along the San Juan River (Nicaragua v Costa Rica) (Judgment) [2015] ICJ Rep 665, 717-718 [140]-[142].

38. Dispute Regarding Navigational and Related Rights (n 34) 267 [150].

39. ILC, 'Report of the International Law Commission on the Work of its Fifty-Third Session, 23 April-1 June and 2 July-10 August 2001, Official Records of the General Assembly, FiftySixth Session, Supplement No. 10' UN Doc A/56/10, ch IV (ILC Articles on State Responsibility). Art 30 states: 'The State responsible for the internationally wrongful act is under an obligation: (a) to cease that act, if it is continuing; (b) to offer appropriate assurances and guarantees of non-repetition, if circumstances so require'. 
whose aim was to include every kind of new relations which may arise, in international law, from the internationally wrongful act of a State. ${ }^{40}$

The second point deals with the lack of a precise determination of a specific regime of liability for breaches of a peremptory norm. ${ }^{41}$ In this respect, one can only note a reiteration in the Court's jurisprudence of the minimum rule laid down in Article 41(2), that of non-recognition of the situation created by a violation of an erga omnes obligation. ${ }^{42}$ This requirement had already been formulated in the advisory opinion of the Court in the Namibia case $(1971)^{43}$ and reiterated in 2004 in the advisory opinion on the Wall. ${ }^{44}$ One may simply add to this state of affairs the reference made by the Court in the recent advisory opinion on the Legal Consequences of the Separation of the Chagos Archipelago from Mauritius in 1965, of 25 February $2019,{ }^{45}$ to the duty of all States to cooperate to enable the people of the Chagos to exercise their right to self-determination. ${ }^{46}$ While the Court's caution in this regard may be regretted, it can be largely explained by the weakness of the ILC Draft Articles, in which an accurate description of the legal regime of responsibility for breaches of a rule of essential importance to the international community as a whole would be sought in vain. Neither Article 42 nor Article 48 provides a comprehensive and substantial legal regime for this situation. The Articles, based on an incorrect distinction between 'injured' and 'non-injured' States, indeed say very little on what the so called 'non-injured' States (ie the member States of the international community other than the one directly reached in its individual rights) ${ }^{47}$ can do in order to obtain reparation from the responsible State for legal damage to the international peremptory legality. This is an important point which the present author has dealt with elsewhere. ${ }^{48}$ The whole of this issue or responsibility for damage to the international community is in any event to be put in connection with what will be said hereafter on the case law of the Court with regard to the qualification of a norm as belonging to jus cogens as such; as a matter of law, the secondary regime

40. ILC, 'Third Report on State Responsibility by Special Rapporteur Mr. Roberto Ago' (1971) UN Doc A/CN.4/246 and Add.1-3, 203, para 19.

41. See Pierre-Marie Dupuy, 'The Deficiencies of the Law of State Responsibility Relating to Breaches of Obligations Owed to the International Community as a Whole: Suggestions for Avoiding the Obsolescence of Aggravated Responsibility' in Antonio Cassese (ed), Realizing Utopia (OUP, Oxford 2012) 210.

42. ILC Articles on State Responsibility (n 39) art 41(2): 'No State shall recognize as lawful a situation created by a serious breach within the meaning of article 40 , nor render aid or assistance in maintaining that situation'.

43. Legal Consequences for States of the Continued Presence of South Africa in Namibia (South West Africa) Notwithstanding Security Council Resolution 276 (1970) (Advisory Opinion) [1971] ICJ Rep 16, 55-56 [122]-[127].

44. Legal Consequences of the Construction of a Wall in the Occupied Palestinian Territory (Advisory Opinion) [2004] ICJ Rep 136 (Wall Advisory Opinion) 200 [159].

45. Legal Consequences of the Separation of the Chagos Archipelago from Mauritius in 1965 (Advisory Opinion) General List No 169 [2019] ICJ 1, 42-43 [180].

46. Which is to be found at art 41(1) of the ILC Articles on State Responsibility (n 39).

47. But these States are indeed injured, although in a different way. They suffer legal damage since the integrity of the part of the legal order composed by peremptory norms, to which each of them has a right, has been breached.

48. Dupuy (n 41) 215-217. 
of liability is directly linked with the recognition of the specificity of a primary rule as being of a peremptory character. ${ }^{49}$

\subsection{Evolution of the material unity}

The evolution of the substantive unity of international law is to a very large extent, and in the broadest sense of the term, a matter of opinio juris. For the generic assertion of the existence of a peremptory norm initially made in Article 53 of the Vienna Convention to be consolidated and definitively validated, it is necessary for interpreters of international law to recognise and designate or qualify some particular norms as belonging to this eminent category. In this respect, in order to observe whether the last 20 years show any change, one must therefore look at how these interpreters have behaved. There are at least two kinds of them (if one disregards the legal literature which, in practice, does not have the same importance). One is the international judge and, as a matter of priority, the ICJ. The other is the States themselves.

With regard to judicial interpretation, ${ }^{50}$ and that of treaties in particular, from the viewpoint of the unity of international law conceived as a structured and coherent whole, one provision is endowed with particular potential. It is the one to be found in Article 31(3)(c) of the Vienna Convention. This provision sets out a rule of customary law, as the ICJ has had occasion to note in the Case Concerning Kasikili/Sedudu Island between Botswana and Namibia. ${ }^{51}$ After mentioning the taking into account of (a) any subsequent agreement between the parties regarding the interpretation of the treaty or the application of its provisions as well as (b) any subsequent practice in the application of the treaty which establishes the agreement of the parties regarding its interpretation, subparagraph (c) indicates that 'the treaty provision concerned must also be interpreted in the light of (c) "any relevant rules of international law applicable in the relations between the parties". ${ }^{52}$ The need to situate the interpretation of an international obligation of a State in the general normative context in which it takes place is of course by no means new. Hersch Lauterpacht rightly observed in The Function of Law:

[I]nternational law is not a coherent and harmonious system of precepts governed by an allpervading unity of the reign of law, but a body of rules largely built up as a generalization of conflicting practices, and attempting to bind together by law political entities each inclined to insist on being a law unto itself. ... [The lawyer's] task is to examine ... whether they are consistent with the whole body of international law conceived as a scientific system. ${ }^{53}$

Commenting on Article 31(3)(c), some authors have expressed the view that this text is to be considered as the reformulation of a genuine, quasi-constitutional principle

49. But this is another opportunity to point to the interconnection between formal and substantial unity or, to put it another way, between primary and secondary norms.

50. Although the provisions of arts 31 and 32 of the VCLT (n 11) are of course not restricted to use by the international judge, in practice, this is first of all a matter for the judge or arbitrator to deal with.

51. Kasikili/Sedudu Island (Botswana v Namibia) (Judgment) [1999] ICJ Rep 1045, 10591060 [18]-[19] without explicit reference to the ILC Articles on State Responsibility, which were not yet finalised.

52. VCLT (n 11) art 31(3)(c).

53. Hersch Lauterpacht, The Function of Law in the International Community (Clarendon Press, Oxford 1933) 428, 45. 
of systemic integration, capable of guaranteeing the coherence of the international legal order as a whole. ${ }^{54}$ Since the obligations to which States are subject are interpreted taking account of each other, an adjustment would be made so that no material contradiction between them would remain. If this were the case, the existence of such a principle could indeed be of great utility in view of the increasing complexity of contemporary international law covering an expanded number of fields. The content of Article 31(3)(c) as an integrative principle would require an interpretation to be sought; it would imply either the compatibility of the rules among themselves or the formulation of an order of priority which would allow some rules to prevail over others. From an even wider perspective, understood from this systematic point of view, Article 31 (3)(c) would reseal the potential of a provision for resolving conflicts of law in public international law. In an order involving jus cogens, which implies a normative hierarchy, this constraint of co-ordination as well seems all the more logical.

During the discussion of the reports on the 'fragmentation' of the law within the ILC (reports which, incidentally, were never adopted by the Commission itself), the idea had arisen that, faced with a possible contradiction between two treaty norms, the judge or arbitrator, in particular, relying on Article 31(3)(c) of the Vienna Convention, could if necessary either interpret a treaty provision by reference to another treaty provision contained in another treaty equally binding on both parties, or invoke the application of a rule borrowed from general international law (thus binding on all) to avoid a possible normative conflict. ${ }^{55}$ The analysis of the case law, however, calls for caution with regard to the general assertion that such a mechanism for resolving normative conflicts on this basis has already become of ordinary use. This remains true even if it is correct to say that express reference to Article 31(3)(c) is already to be found in contemporary international case law, particularly that of the ICJ. When faced with the need to interpret a treaty provision, the Court has several times made general reference to Article 31 of the Vienna Convention, often with a special mention of its paragraph 3 . However, even beyond such a reference, in the end it is not always used decisively in the Court's actual reasoning, as the Court often considers that in the case at stake it has no reason to use it, an option retained in the Pulp Mills case between Argentina and Uruguay ${ }^{56}$ or recently in the Jadhav case between India and Pakistan. ${ }^{57}$ Nevertheless, the Court sometimes explicitly interprets a treaty provision binding on the parties to the dispute in light of a particular article of another convention which it knows is also binding on the same countries. An example of this practice is provided in the Case Concerning Certain Questions of Mutual Assistance between Djibouti and France, in 2008. ${ }^{58}$ A more recent example is

54. William Mansfield and Campbell McLachlan, 'Study on: "The interpretation of treaties in the light of 'any relevant rules of international law applicable in the relations between the parties' (article 31(3)(c) of the Vienna Convention on the Law of Treaties) in the context of general developments in international law and concerns of the international community" (2004) UN Doc ILC(LVI)/SG/FIL/CRD.3/Rev.1 presented at the fifty-sixth session of the ILC in 2004, see ILC, 'Report of the International Law Commission on the Work of its Fifty-Sixth Session' (3 May-4 June and 5 July-6 August 2004) UN Doc A/59/10, paras 298 and 345-351. 55. See this point reflected in the study group's final report: ILC, 'Report of the Study Group of the International Law Commission, Finalized by Martti Koskenniemi' (2006) UN Doc A/ CN.4/L.682, paras 411-413.

56. Pulp Mills on the River Uruguay (n 35) 46 [65].

57. Jadhav Case (India v Pakistan) (Judgment) General List No 168 [2019] ICJ 1, 36 [135].

58. Certain Questions of Mutual Assistance in Criminal Matters (Djibouti v France) (Judgment) [2008] ICJ Rep 177, 219 [112]-[114]. 
provided by the 2017 Judgment on Preliminary Objections in the Somalia-Kenya Maritime Delimitation case: the Court interpreted the memorandum of understanding binding on the two parties in the light of the relevant provisions of the United Nations Convention on the Law of the Sea, ratified by both States. ${ }^{59}$

From there, in order to speak of a systematic and widespread use of the rule set out in Article 31(3)(c) elevated to the rank of a 'principle' by the international judge, there is nevertheless still a long way to go! Even taking into account arbitral awards (in particular between States and foreign investors) that also make use of this provision, ${ }^{60}$ it does not seem realistic, in the current state of international jurisprudence, to speak of the progressive establishment of a true principle of systemic integration in positive international law. The integrative potential of taking into account any relevant rules of international law applicable in the relations between the parties remains certain; but the importance and effects that will be given to it will ultimately depend on the long-standing judicial policy of international courts (not forgetting the European Court of Human Rights and, even more so, the Inter-American Court of Human Rights, which are often bolder than the principal judge of the United Nations). As for the ICJ, it will most probably go on making only a careful and moderate use of this means of interpretation. Indeed, the very wording of Article 38 of its Statute prompts the Court first and foremost to apply, as a matter of priority, the specific rules binding on the parties in a given dispute. Article 31(3)(c) of the Vienna Convention seems to remain so far for the international judge, what it is in itself: a useful accessory to the interpretation of the treaty rules applicable to a given situation. One should be conscious of the fact that the spirit of the system or the academic "constitutionalist' trend underlying the idea of systemic integration is much more present in part of the doctrine than in the minds of the judges of the ICJ, whose diversity of opinions reflects that of the composition of the body to which they belong.

Let's turn now, taking the view that qualification is part of interpretation, to the way in which the ICJ considered some primary rules and, implicitly or, after a number of decades, explicitly, accepted to qualify them as pertaining to the upper category of jus cogens norms. ${ }^{61}$ International case law is of course to be enhanced by the fact that within the space of one year, from February 2006 to February 2007, the Court twice held that the norm prohibiting genocide was a norm of jus cogens, apparently overcoming its reluctance to pronounce the word, which it had not done since its 1979 Order in the Diplomatic Staff case in which it spoke of an 'imperative obligation'. It did so first in its 2006 Judgment in the Armed Activities on the Territory of the Congo case between the Republic of Congo and Rwanda, ${ }^{62}$ and then in 2007 in the Genocide case between Bosnia and Herzegovina, on the one hand, and Serbia and Montenegro, on the other. ${ }^{63}$ In the first case, however, it would contextualise the

59. Maritime Delimitation in the Indian Ocean (Somalia v Kenya) (Preliminary Objections) [2017] ICJ Rep 3, 37-38 [89]-[91].

60. See eg Philip Morris v Uruguay, ICSID Case No ARB/10/7, Award, 8 July 2016, [290], [317].

61. Pierre-Marie Dupuy, 'Le "jus cogens", les mots et les choses: où en est le droit impératif devant la Cour internationale de Justice près d'un demi-siècle après sa proclamation?' in PierreMarie Dupuy, Mélanges offerts à Charles Leben, Droit international et culture juridique (Pedone, Paris 2015) 77, reprinted in Pierre-Marie Dupuy, Ordre juridique et désordre international (Pedone, Paris 2018) 171.

62. Armed Activities on the Territory of the Congo (New Application: 2002) (Democratic Republic of the Congo v Rwanda) (Jurisdiction and Admissibility) [2006] ICJ Rep 6, 32 [64].

63. Bosnia Genocide (n 33) 111 [161]. 
finding by reference to the East Timor precedent in order to excuse itself from giving effect to any normative consequence whatsoever. ${ }^{64}$ In the second case, admittedly, the observation that the obligation not to commit genocide was imperative was not subsequently associated with a finding that the Court lacked jurisdiction to rule on the case. It is nevertheless striking that, after its lengthy disquisition interpreting the meaning and scope of the 1948 Convention on the Prevention and Punishment of the Crime of Genocide, and Article 1 in particular, ${ }^{65}$ at no time did the Court rely on the imperative nature of the prohibition it believed it discerned in that article (even though it contains no such explicit prohibition).

As a matter of fact, a paradox seems to dominate the development of the Court's case law on jus cogens: it was much closer to recognising it when it did not use the concept explicitly. ${ }^{66}$ It was at the outset, from 1949, in the Corfu Channel case when it referred to 'elementary considerations of humanity', that the Court's underlying inspiration clearly dovetailed with human rights and the 'elementary' or 'cardinal' principles of humanitarian law. ${ }^{67}$ It relied again on the same inspiration in 1951 with the Opinion on Reservations to the Convention on Genocide, ${ }^{68}$ and then in 1986 in the Nicaragua $v$ United States Judgment, ${ }^{69}$ and again in 1996, in its Opinion on the Legality of the Threat or Use of Nuclear Weapons. ${ }^{70}$ It should also be noted that the rules thus identified are regarded as 'even more exacting in peace than in war' (or 'plus absolues' in the French) in the 1949 and 1986 Judgments, and as 'fundamental to the respect for the human person' because they are 'intransgressible principles of international customary law' in the 1996 Opinion. ${ }^{71}$ Then, in its Advisory Opinion on the Legal Consequences of the Building of a Wall in the Occupied Palestinian Territory delivered on 9 July 2004, in relation to the most fundamental obligations of humanitarian law, the Court would once again refer to its own 1996 Opinion, restating (which was significant in the case before it, given Israel's situation in relation to the 1949 Geneva Conventions) that because those obligations were among the 'elementary considerations of humanity' they must, consequently, 'be observed by all States whether or not they have ratified the conventions that contain them, because they constitute intransgressible principles of international customary law'. ${ }^{72}$

In 2012, the Court's case law seemed to show a different picture. The reality was much more nuanced, however. On 3 February, in its Judgment in Jurisdictional Immunities of the State, the Court was confronted with the need, which it had not

64. Armed Activities on the Territory of the Congo (New Application: 2002) (n 62) 32 [64] referring to East Timor (Portugal v Australia) (Judgment) [1995] ICJ Rep 90, 102 [29] ('the erga omnes character of a norm and the rule of consent to jurisdiction are two different things'). 65. See Bosnia Genocide (n 33) 109-119 [160]-[179].

66. See Pierre-Marie Dupuy, 'From a Community of States Towards a Universal Community?' in Ricardo Pisillo-Mazzeschi and Pasquale De Sena (eds), Global Justice, Human Rights and the Modernization of International Law (Springer, Cham 2018) 47, 61.

67. Corfu Channel Case (UK v Albania) (Judgment) [1949] ICJ Rep 4, 22. See also the reference to 'cardinal' principles of international humanitarian law in Legality of the Threat or Use of Nuclear Weapons (n 22) 257 [78].

68. Reservations to the Convention on Genocide (Advisory Opinion) [1951] ICJ Rep 15, 23. 69. Military and Paramilitary Activities in and against Nicaragua (Nicaragua v United States of America) (Judgment) [1986] ICJ Rep 14 (Nicaragua) 112 [215].

70. Legality of the Threat or Use of Nuclear Weapons (n 22) 257 [79].

71. Corfu Channel Case (n 67) 22; Nicaragua (n 69) 112 [215]; Legality of the Threat or Use of Nuclear Weapons (n 22) 257 [79] (emphasis added).

72. Wall Advisory Opinion (n 44) 199 [157]. 
encountered before, to choose between an intangible defence of, on the one hand, the 'fundamental rights of the State' in the various forms of immunity from jurisdiction, and, on the other, of elementary rules of humanitarian law, in relation to which it would seem to call into question that they even belonged to peremptory law, thereby introducing a risk of contradicting its 1986 and 1996 case law. The choice that the Court made was to erect an unbroken barrier between procedure and substance, which seemed to rely on the apparent similarity between the finding, for its part perfectly consistent with its Statute, that the Court cannot hear a case without the consent of the party concerned, and the assertion, in itself incompatible with the rationale of the peremptory nature of norms, that such peremptory force can have effect only in relation to primary rules but not procedural rules. ${ }^{73}$

However, in the same year, some time later, on 20 July, the discourse held by the Court in Questions Relating to the Obligation to Prosecute or Extradite between Belgium and Senegal apparently seemed, at first glance, to be completely different. ${ }^{74}$ The Court had no qualms about seeing the Convention against Torture, taken as a whole, as a treaty setting out erga omnes partes obligations, in order to find grounds for Belgium's right to bring proceedings. If one advocates an international ordre public in terms of protecting certain fundamental rules, even where they are established by means of conventions, why not applaud this position? One is even tempted to recall that in 1951 the Court had furthermore held, in relation to the Genocide Convention, that 'the principles underlying the Convention are principles which are recognized by civilized nations as binding on States, even without any conventional obligation'. ${ }^{75}$ Even if, in 2012, the Court did not go as far as that, it nevertheless pointed to the very nature of these general obligations to suggest that they are endowed with a special authority.

Whatever the case may be, that last Judgment should not, however, be seen as contradicting the one which just came before in the same year. What was at stake in the two cases was very different. The second related only to a finding against Senegal for infringing obligations which it had itself accepted by becoming a party to the Convention against Torture. It is, admittedly, important, but is, in essence, merely a very classic application of the pacta sunt servanda rule. In contrast to the position in Jurisdictional Immunities of the State, the judges here were not faced with a head-on clash between, on the one hand, certain rights attaching to State sovereignty, and, on the other, the need to uphold obligations relating to the rights of the human person, as occurred in the Jurisdictional Immunities of the State case. What the judges seem to find quite impossible is that, as a result of the development of general international law, the States from which the Court derives its jurisdiction should be forced by the existence of peremptory rules, which in essence are customary rules, to refrain from in any way extending rights which those same full subjects of the international legal order hold as sovereign States. However, the 20 July 2012 Judgment in Questions Relating to the Obligation to Prosecute or Extradite reveals that, within the limits described above, the Court can definitely play a part in consolidating the identification of certain fundamental rights of the person as belonging not only to customary international law but also to jus cogens. It can also (which is not the same thing) identify certain

73. Jurisdictional Immunities of the State (n 36) 140-141 [94]. See in that regard the interesting discussion in the Dissenting Opinion of Judge Yusuf to the aforementioned Judgment.

74. Questions Relating to the Obligation to Prosecute or Extradite (Belgium v Senegal) (Judgment) [2012] ICJ Rep 422, 457 [99].

75. Reservations to the Convention on Genocide (n 68) 17. 
obligations as being erga omnes, even if only in relation to the States Parties to a general multilateral convention. Generally speaking, it remains correct to say, as Judge Manfred Lachs did in the Lockerbie case, that the Court is 'the guardian of legality for the international community as a whole, both within and without the United Nations'. ${ }^{76}$

The Order on provisional measures most recently delivered on 23 January 2020 in the Application of the Convention on the Prevention and Punishment of the Crime of Genocide (The Gambia v Myanmar) is noteworthy in several respects. The Court refers in new faith, as it did for the last time in the 2012 case between Belgium and Senegal, to the analysis already made by it in 1951 of the 1948 Genocide Convention:

In such a convention the contracting States do not have any interests of their own; they merely have, one and all, a common interest, namely, the accomplishment of those high purposes which are the raison d'être of the convention. Consequently, in a convention of this type one cannot speak of individual advantages or disadvantages to States, or of the maintenance of a perfect contractual balance between rights and duties. ${ }^{77}$

It is on this basis of obligations erga omnes partes that the right of the Gambia is recognised to bring an action against Myanmar, since both States are parties to the aforementioned 1948 Convention. Relying on the recent resolutions adopted by the United Nations General Assembly ${ }^{78}$ and the conclusions of the fact-finding mission established in relation to the treatment of the Rohingyas by the military and paramilitary forces controlled by Myanmar, the Court, without explicitly recalling that it had previously held that the prohibition of genocide was a norm of jus cogens, nevertheless makes the following finding:

In view of the fundamental values sought to be protected by the Genocide Convention, the Court considers that the rights in question in these proceedings, in particular the right of the Rohingya group in Myanmar and of its members to be protected from killings and other acts threatening their existence as a group, are of such a nature that prejudice to them is capable of causing irreparable harm. ${ }^{79}$

It is, in other terms, on the basis of the established facts relating to the characterisation of the wrongful act which they are likely to constitute (an issue which will be assessed in its judgment on the merits) that the Court has ordered provisional measures consisting in particular in taking 'all measures within its power to prevent the commission of all acts within the scope of Article II of this Convention' ${ }^{80}$ It may therefore be noted that, in this Order, the Court confirms the positive attitude already perceptible at least in the second of its two Judgments of 2012 and gives reason to hope that in the future judgment on the merits, it will be able to draw all the consequences in

76. Case Concerning Questions of Interpretation and Application of the 1971 Montreal Convention Arising from the Aerial Incident at Lockerbie (Libyan Arab Jamahiriya v United Kingdom) (Order) (Separate Opinion of Judge Lachs) [1992] ICJ Rep 3, 27.

77. Application of the Convention on the Prevention and Punishment of the Crime of Genocide (The Gambia v Myanmar) (Order) General List No 178 [2020] ICJ 1 (The Gambia v Myanmar) 13 [41]; Questions Relating to the Obligation to Prosecute or Extradite (n 74) 422 [68] both quoting Reservations to the Convention on Genocide (n 68) 23.

78. Including UNGA Res 74/246 (27 December 2019) UN Doc A/RES/74/246, preambular para 25.

79. The Gambia v Myanmar (n 77) 21 [70].

80. Ibid 25 [86(1)]. 
terms of Myanmar's international responsibility for the commission or cover-up of this 'crime under international law' to use here the legal definition of genocide.

The interpretation of international law, in particular the meaning and scope of primary norms, is also the result of action and declarations by State organs. In both respects, certain developments that have occurred over the last 20 years may give rise to concern about the maintained authority of some of the most established rules of international law. This is the case, albeit a longstanding one, in the field of human rights, but it is the case also with regard to the principle that no acquisition of territory can be achieved by the use of force. However, despite the Court's advisory opinion issued in 2004, among others, it has been observed in other regions of the world that the prohibition on territorial annexation through use of force (even if subsequently covered by the recourse to a referendum supposed to respect the right of peoples to self-determination) had not been spared. Still in the area of the use of force, the trivialised use of killer drone attacks seems difficult to reconcile with certain 'cardinal' principles of humanitarian law. China's construction of certain military installations between islets in the South China Sea and its claims to the entire South China Sea region also pose serious problems in terms of international legality. ${ }^{81}$ The principle of non-intervention in internal affairs is also increasingly being violated by the use of social networks and other information technology to influence the outcome of free elections in foreign countries. The systematic questioning of multilateralism and cooperation, particularly in the field of international trade, and the use of 'trade wars' blatantly flout the established system of international trade, whose dispute settlement system is largely paralysed by unilateral actions. Finally, the strong statements of some leaders taking the floor in the United Nations General Assembly with a view to glorifying the most archaic version of nationalism would almost suggest that some of the very foundations of the UN Charter are now being attacked according to an established plan.

If, however, one tries to make a general assessment by testing the theory of the two unities when confronted with the facts as well as the evolution of the law, one can conclude, it seems, at least at the present time, that its validity is unfailingly maintained. The aggressive and unqualified statements of populist leaders have provoked strong protests all over the world, particularly at the United Nations. The assertion that multilateralism should be maintained and that it is more necessary than ever at a time when the planet is or should be struggling for the survival of its climate is hardly a matter of doubt for the majority of peoples and their leaders. As a matter of law, the recognition by the ICJ and many other tribunals of the existence of jus cogens, however belated and incomplete it may be, and the explicit designation of certain primary norms, including the prohibition of genocide, as belonging to it, make it possible to affirm that the foundation of material unity remains truly alive.

Nevertheless, all must keep being vigilant in the face of the rise of some of the ideologies which have in the past plunged the international community into an era of disasters. In the face of such developments as those mentioned earlier, some of which are due to the first consequences of technological change (digitalisation) and others to the rising anxiety of many peoples about the economic and social consequences of globalisation (rise of populism), one may depart somewhat from the neutrality generally required from scholars to affirm that the international rule of law, of

81. Florian Dupuy and Pierre-Marie Dupuy, 'A Legal Analysis of China's Historic Rights Claim in the South China Sea' (2013) 107 AJIL 124. 
which jus cogens is or should be the epicentre, is itself part of the common heritage of mankind.

It is undoubtedly for its analysts (this means us, the international lawyers), among others, to recall that the rule of law does exist and that it is still in force for every State. And here it is more necessary than ever to recall the words of Sir Hersch Lauterpacht when he said: 'No doubt it is true to say that international law is made for States, and not States for international law, but it is true only in the sense that the State is made for human beings'. ${ }^{82}$

82. Lauterpacht (n 53) 430-431. 